Check for updates

Montreal

Cite this as: $B M J 2020 ; 371: \mathrm{m} 4927$ http://dx.doi.org/10.1136/bmj.m4927 Published: 22 December 2020

\title{
Covid-19: Police enforcement of restrictions is often abusive and counterproductive, charges Amnesty International
}

Owen Dyer

Governments and police forces around the world have often used the covid-19 pandemic as an excuse to roll back freedoms, crush dissent, and target minority groups, Amnesty International has charged in a new report.

Even sincere efforts by police to contain the spread of the virus often do more harm than good, the human rights group claims, by packing people into crowded cells or, in some cases, even opening fire on the very people whose health they are charged with protecting.

"Security forces all over the world are widely violating international law during the pandemic, using excessive and unnecessary force to implement lockdowns and curfews," said Patrick Wilcken of Amnesty International's global issues programme. "Abuses committed on the pretext of fighting covid-19 include Angolan police shooting a teenage boy in the face for allegedly breaking curfew, and police in El Salvador shooting a man in the legs after he went out to buy food."

The problem is perhaps most acute in Africa, where the pandemic has exacerbated class tensions. Governing elites, fearing the virus, tend to favour strict lockdowns, but the urban poor, with no safety net, often feel more at risk from diseases of poverty and hunger if barred from daily participation in the informal economy.

On 27 March Kenyan police attacked with tear gas and batons a crowd waiting at Mombasa's Likoni terminal to catch the last ferry home before curfew. Hundreds of civilians were forced to lie down, many piled on others, coughing and vomiting from the tear gas.

Kenyan police killed at least 15 people in the first nine weeks of the curfew, the country's Independent Policing Oversight Authority reported. Most large African countries have since seen cases of curfew related shootings by police.

Covid-19 has also brought a surge in prison riots and protests, and their violent suppression, in Thailand, Iran, Indonesia, the United States, and across Latin America. Eight inmates were killed and 60 injured when guards opened fire on rioters at Mahara prison near Colombo, Sri Lanka, on 29 November. Prisoners' relatives said they had rioted after officials ignored their pleas for coronavirus testing and separation of infected inmates.

Minority groups have often been targeted with especially harsh restrictions. In Bulgaria and Slovakia, Roma communities were cordoned off by police and soldiers, and some Bulgarian cordons remained in place even after general lockdowns were lifted, as authorities argued that residents' "lack of discipline" demanded special measures to "protect the general population."2

In Cyprus a controversial plan to detain asylum seekers in closed camps was suddenly presented as a public health measure with the pandemic's arrival. When lockdown measures were lifted, the main camp remained locked, despite reporting no covid-19 cases. The government declared an outbreak of scabies and prohibited residents from leaving on public health grounds.

Covid-19 has also proved useful to governments seeking to roll back free expression. In Namibia social distancing rules were used to exclude privately owned media from government press conferences, while allowing state media to remain. In Greece, police banned outdoor assemblies for just four days in November, four days that happened to coincide with the annual demonstrations commemorating the 1973 student uprising against the military government.

Laws passed against spreading misinformation or impeding public health measures are often used against critics of governments' pandemic responses, as in Turkey, where at least 510 people, including doctors, have been questioned or detained over critical social media posts. Governments typically claim such measures are temporary, but most of the new “misinformation” laws, like Hungary's, which carries a potential five year prison sentence, have no expiry date.

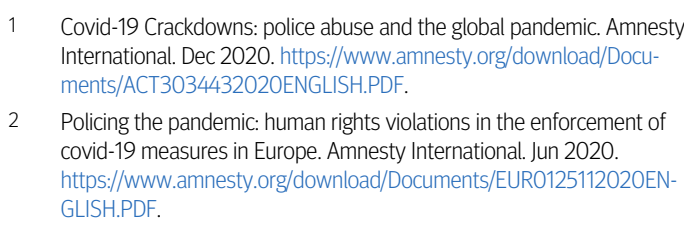

Covid-19 Crackdowns: police abuse and the global pandemic. Amnesty International. Dec 2020. https://www.amnesty.org/download/Documents/ACT3034432020ENGLISH.PDF.

2 Policing the pandemic: human rights violations in the enforcement of covid-19 measures in Europe. Amnesty International. Jun 2020. https://www.amnesty.org/download/Documents/EUR0125112020ENGLISH.PDF.

This article is made freely available for use in accordance with BMJ's website terms and conditions for the duration of the covid-19 pandemic or until otherwise determined by BMJ. You may use, download and print the article for any lawful, non-commercial purpose (including text and data mining) provided that all copyright notices and trade marks are retained. 